succeeded in developing a kind of artificial rubber which seems to possess several good qualities. Production on a small scale has been going on for some time at one of the rubber factories of the Swedish Co-operative Wholesale Society, which is supporting his researches and will probably exploit the new product. It belongs to the so-called 'thioplast' products, the weak point of which has hitherto been that they could not be vulcanized at a high temperature. This can, however, be done with the Ehrensvärd rubber. The unpleasant odour that formerly characterized such products has also been eliminated. Nothing has so far been said about the composition of the new product or of what raw materials it is being made, except that it is based on domestic raw materials and that the Swedish forests, in this as in so many other cases, will play an important part.

\section{Photographic Analysis of Motion}

A LECTURE on the "Photographic Analysis of Motion" was delivered at the Royal Institution on December 11 by Mr. E. R. Davies, director of research, Messrs. Kodak, Ltd. He said that the value of photography in the analysis of movements too rapid for the eye to follow was demonstrated, and the method successfully applied, in the classical investigations of Muybridge and Marey before the introduction of the dry plate in 1871. The great convenience of the new process compared with the laborious wet-plate technique, and its enhanced sensitivity, brought about many triumphs towards the end of the nineteenth century. The movements of animals and the flight of birds were analysed; projectiles travelling at speeds in excess of that of sound photographed; and the propagation of flames in gaseous combustion was followed. Modern progress had depended to a large extent upon the introduction of the cold cathode discharge tube in place of the far less luminous electric spark; on advances in the design of cinematographic and other types of camera; on the introduction of photographic materials of greatly increased sensitivity; and on the application of the photo-electric cell and the microphone to the problem of synchronizing the action with the camera exposure. Instantaneous photographs can now be taken with exposures of less than a millionth of a second and cinematograph pictures with a frequency in excess of 4,000 a second. A valuable tool has become available to science and industry, and has proved its worth in many fields. Its use in the design and testing of high-speed machinery is of particular importance at the present time.

\section{Cancer-producing Mineral Oils}

Addressing a recent meeting of the Manchester University Branch of the Association of Scientific Workers, Mr. R. Lyth described how methods of preventing certain types of occupational cancer have been discovered. External cancers which are prevalent among Scottish shale oil workers have also increased among cotton spinners, since the introduction of mineral lubricating oils. In the Cancer Research Department of the University of Manchester, cancers have been produced in mice by repeatedly painting their skins with mineral oils. Shale oil was found to be much the most active carcinogenically, while Russian oil was one of the least active oils. The refractivity $(\mu-1) / D$, where $\mu$ is the refractive index and $D$ the density, could be roughly correlated with the carcinogenic properties, and used as an index of them. In the laboratory, various methods of reducing the activity of oils were found, but the cotton industry has found it more practicable to avoid the use of the more dangerous oils such as shale oil. For the shale oil workers themselves, the regular use of certain ointments has proved beneficial. Efforts to isolate the carcinogenic constituents of mineral oils have not yet fully succeeded. The meeting learnt with regret that the Cancer Research Department of the University of Manchester is being closed.

\section{Frequency Stability of Radio Circuits}

AT a meeting of the Students Section of the Institution of Electrical Engineers held on November 16, Mr. C. W. Eggleton read a paper on "The Frequency Stability of Tuned Circuits". The author dealt with the conditions with which it is necessary to comply in the design of commercial radio receivers in order to secure a satisfactory degree of frequency stability in the various tuned circuits of the receiver. The majority of broadcasting receivers in use at the present time are of the supersonic heterodyne type using a local oscillator, and it is the frequency stability of this oscillator which usually determines the stability of the whole receiver, particularly when the required reception is within the short-wave band. Variations of the frequency of any tuned circuit are occasioned chiefly by the effect of temperature, and to a lesser extent by condensed moisture, on the electrical characteristics of inductance coils and condensers. In the paper, the author directed attention to the desirable properties of the materials used in the construction of these components, and to the importance of various features of design. An important point in connexion with the layout of the whole recejver is to ensure that the local oscillator and the main radio frequency circuits are kept as far away as possible from the power frequency components, which largely form the main source of heat generated in the receiver.

\section{London Gulls}

IT is reputed (Countryside, 12, No. 5, $93 ; 1942$ ) that it is exactly fifty years since flocks of gulls began to winter on the London Thames, in the severe winter of 1892. Most of these birds are black-headed gulls, but whether or not the severe winter of 1892 was the origin of gulls frequenting the Thames embank. ment in numbers is not accepted by all ornithologists. T. L. Bartlett notes that sixty years ago the occasional appearance of gulls in London caused unusual interest amongst ornithologists, and although there were occasional records of gulls passing up-river in severe weather, the first winter occupation of central London by black-headed gulls appears to be the severe winter of 1892 at Blackfriars Bridge, where new legislation protected them from gunshot. But the black-headed gull has not really changed its habit : it was always known as an inland as well as coastal bird. The difference in the past fifty years has been its great increase in numbers-which may be from biological reasons-and its protection under the bird laws which give it encouragement to stay on waters where formerly it was persecuted and driven away. Bartlett, however, suggests also that they were encouraged to winter on the Thames after 1892 by the public feeding the gulls with large sprats, and fifty years of embankment feeding with bread have changed its ways to a town gull. The habits of Thames gulls have, how ever, been given exaggerated importance. Similar 
changes in the status of the black-headed gull have occurred in the Mersey and other rivers where there was no great public feeding of the gulls, and the flocks became regular winter inhabitants of the park lakes.

\section{Regional Survey Atlas of the Croydon District}

THE ambitious project for a regional survey atlas covering some 200 square miles around the Borough of Croydon was begun by the Croydon Natural History and Scientific Society so long ago as 1913. Despite the difficulties of war-time conditions, it has been continued by the issue this year of a third series of maps and printed matter (Proc. Croydon and Dist. Nat. Hist. and Sci. Soc.). In contrast to similar local surveys which have been attempted in other parts of Great Britain, the Croydon scheme is based essentially on the idea that a regional survey is never of necessity complete, and hence the actual work is to be contained in a loose-leaf binder which was issued with the first series of maps; the contents as originally planned can therefore be added to as experience and the progress of knowledge may dictate.

The two previous issues of maps have included base maps, maps dealing with rainfall, relief, drainage and a number of historical maps as well as some referring to population and planning. The present, or third, issue contains only one map-of bronze age remains-but has the textual statement by Mr. Fagg on geological structure and history, illustrated by geological sections, and an account of the natural vegetation, together with a list of plants normally found on the chalk of the region, a section contributed by Mr. C. T. Prime. The description of the bronze age map is by Mr. A. W. G. Lowther. It is to be hoped that there will be sufficient public support for the venture to enable it to be continued and to afford the necessary encouragement to $\mathrm{Mr}$. C. C. Fagg, who has been the organizer.

\section{Indian Forest College, Dehra Dun}

The Progress Report of the Indian Forest College, Dehra Dun, 1940-41 (Manager, Government of India Press, New Delhi, 1941), states that the College was opened in May 1938, after a period of closure, for the training of candidates for the Superior Forest Services of the various Provinces and States of India. The course extends over two years, each class completing its course before a fresh class is admitted, so that there are no overlapping classes. This first course lasted from May 1938 until March 1940. The report in question covers the first year's work of the second course, which was to end in March 1942. At the prize-giving at the end of the first two-year course the President and Principal of the College both spoke in laudatory terms of the work achieved and the type of man and training which the College is turning out.

The movement will be watched anxiously by old Indian forest officers, who have seen the growth of, and the fine results attained by, the Indian Forest Service. They ask how will the standard be main tained by a series of devolutionized, entirely independent forest departments in the provinces, staffed in the higher grades in the future by men trained in a college the staff of which has had no opportunities of rubbing shoulders with confreres in their own subjects. Moreover, men trained in this fashion will not have had the advantage of training in one of the old universities, where they mix with men who are getting other courses of education; and finally they will not have the opportunity of combining this training with visits to European continental forests which is so desirable.

\section{The Night Sky in January}

New moon occurs on January 6d. 12h. $37 \mathrm{~m}$. and full moon on January $21 \mathrm{~d}$. $10 \mathrm{~h} .48 \mathrm{~m}$. The following conjunctions take place during the month: Jan. $4 \mathrm{~d}$. 10h., Mars in conjunction with the moon, Mars $5^{\circ}$ S.; Jan. 7d. 22h., Mercury in conjunction with the moon, Mercury $3^{\circ} \mathrm{S}$.; Jan. 16d. 10h., Mercury in conjunction with Venus, Mercury $2 \cdot 7^{\circ} \mathrm{N}$.; Jan. 16d. 19h., Saturn in conjunction with the moon, Saturn $3^{\circ}$ N.; Jan. 20d. 12h., Jupiter in conjunction with the moon, Jupiter $3^{\circ} \mathrm{N}$. Occultations of stars brighter than magnitude 6 are as follows, the times referring to Greenwich :

$\begin{array}{ccc}\text { d. } & \text { h. } & \text { m. } \\ \text { Jan. } 14 & 19 & \mathbf{4 3 \cdot 2} \\ 15 & 17 & 37 \cdot 7 \\ 16 & 17 & 31 \cdot 0 \\ 16 & 23 & 25 \cdot 6 \\ 16 & 23 & 46 \cdot 6 \\ 17 & 00 & 32 \cdot 9 \\ 25 & 00 & 29 \cdot 8\end{array}$

$\begin{array}{rll}\mu & \text { Ceti } & \text { D } \\ f & \text { Tauri } & \text { D } \\ \gamma & \text { Tauri } & \text { D } \\ \boldsymbol{\theta}^{\prime} & \text { Tauri } & \text { D } \\ 75 & \text { Tauri } & \text { D } \\ \text { 264B. } & \text { Tauri } & \text { D } \\ \chi & \text { Leonis } & \text { R }\end{array}$

Mercury attains its greatest elongation, $19^{\circ} \mathrm{E}$., on Jan. 8. Venus sets about an hour after the sun in the middle of the month and is not very favourably placed for observation in Great Britain. Jupiter and Saturn continue to be well placed for observation, the former southing about midnight and the latter at $20 \mathrm{~h} .40 \mathrm{~m}$. in the middle of the month. The earth makes its closest approach to the sun on January 2.

\section{Announcements}

Sir John C. G. Ledingham is to retire on March 31 from the post of director of the Lister Institute of Preventive Medicine, which he has held since 1930. To succeed Sir John Ledingham in the directorship, the Governing Body of the Institute has appointed Dr. A. N. Drury, Huddersfield lecturer in special pathology, University of Cambridge, and member of the scientific staff of the Medical Research Council.

AT the annual general meeting of the British Mycological Society on December 12, Dr. S. P. Wiltshire, director of the Imperial Mycological Institute, Kew, Surrey, was elected president for 1943.

THE Board of Trinity College. Dublin, has invited Prof. J. M. O'Connor, professor of physiology in University College, Dublin, to deliver the John Mallet Purser Lecture in 1943.

ThE Central Council for Health Education is making plans for its 1943 Summer School. The School will probably be held at the Chelsea Polytechnic during August 4-14, and will deal with the teaching of biology and with health education generally. While teachers of biology will find the full ten days of value, educational administrators and youth leaders will find the first three days of the School of special interest to them. Further details may be obtained from the Education Officer, Central Council for Health Education, Tavistock House, Tavistock Square, W.C.1. 